\title{
P. Ramlee's Cinematographic Auteurship of Cultural Values Representation in Antara Dua Darjat and Ibu Mertua-Ku
}

\author{
NURUL EZZATI AISYA MOHD ZAKI \\ Universiti Tunku Abdul Rahman \\ WAN HARTINI WAN ZAINODIN \\ Universiti Teknologi Mara
}

\begin{abstract}
This paper looks into an investigation on auteur theory's model of cultural representation through visual narrative employment in P. Ramlee's two heavy-dramas: Antara Dua Darjat and Ibu Mertua-Ku. By employing a qualitative approach, case study embedded and thematic analyses implored two concepts; film syntax and cultural values in both film texts. The findings found that $P$. Ramlee employed and manipulated visual narrative conventions in his motivated choices of synchronic (space) and diachronic (time) shots in both film texts. In representing cultural values such as communal, brotherhood, responsibility and manners, P. Ramlee portrayed them through distinguishable utilization of cinematography tools - i.e. taking advantage of deep depth of field in layering actions and emphasizing carriers (actors) of values in medium shots. Finally, through the exhaustive exploration of Antara Dua Darjat and Ibu Mertua-Ku's visual narrative, it was manifested that P. Ramlee fulfilled the characteristics of an auteur as technically competent, infused personality in his works and idiosyncratically instilled interior meanings across his masterpieces. Though studies on P. Ramlee are somewhat saturated, this exploration was initially a challenge to the glorified realm in which P. Ramlee was placed by critics and fans. True to the nature of research, this exploration summed up to an outcome which not only concurs to the filmmaker's adoring critics but also theoretically accords P. Ramlee into the realm of the auteur.
\end{abstract}

Keywords: Film studies, Auteur theory, film syntax, P. Ramlee, cultural values representation.

\section{INTRODUCTION}

Film as a social artefact has been studied by researchers in pursuit of nuances in content produced. The medium vast audience outreach encourages signified elements in many forms to be introduced in their means whether subtly or forcefully by the film industry players; producers, directors, scriptwriters, cinematographers, and editors. The idea of incorporating signified elements, seen done in countless films, was partly to instil understanding about humanity into a short 90 minutes moving images version of the life. Film texts are visual aids to the dynamic relations of culture and while studying films' themes, values and messages are imperative, decoding representation constructed through production techniques should also be highlighted.

Grounded by auteur theory, this study managed to understand P. Ramlee's individual style in cinematography and ways cinematography tools were manipulated to generate meanings in the visual narrative of cultural values. Bordwell, Thompson and Smith (2016) stated that early auteur theory supporters were inclined to champion the director's individuality and consistency in cinematic style. The auteur statured directors were valued through their technical competence in lighting, camerawork, and mise-en-scéne across multiple works. And by exploring directors' tendencies in their choices of cinematography 
tools and signifiers, researchers are able to separate the auteur amongst the metteur en scéne. Analyses on technical elements are important in assessing the director's vision; for a good director must be technically competent in filmmaking processes (Sarris, 1962).

Originally went to Singapore to do music, P. Ramlee started his film career behind the scene as a continuity keeper, clapper boy, and assistant cameraman. With no formal education in filmmaking, P. Ramlee took to his advantage his surrounding and learned composition, camera movement, and camera angle in visualizing narrative, while at the same time moulding his own style and breaking away from the Indian film traditions (Abdullah, 2003; Muhammad Hatta, 2003). As Malaysian legendary filmmaker, many studies had been done in dissecting P. Ramlee's works. From works of literature reviewed, studies done by scholars on P. Ramlee have been mostly thematic analyses of his oeuvre. There are steady continuous researches done to uncover themes, messages, and societal portrayal in the $P$. Ramlee-verse. Prior to film studies in academia, film critics are some of $\mathrm{P}$. Ramlee's biggest fans and notorious criticizers. Critic and scholar Anuar Nor Arai, for example, had written in magazines, newspapers and academic platforms about P. Ramlee's undisputable flair at social representation in his many films. Another reporter-turned-film blogger, Mustafar A. R. or also known as Pak Mus in his popular Filem Klasik Malaysia blog periodically writes discourses about $P$. Ramlee's films, among others, as he unearthed the many underlying messages usually missed by the common everyday audience.

In the 1950s and 1960s, films directed by pioneering Malay directors such as P. Ramlee, Hussain Haniff and M. Amin were among social artefacts progressively honed with direct and indirect criticisms of the postcolonial nation's socio-cultural issues (Wong, Pillai \& Ong, 2018). Film texts touched issues specifically on Malayness and the rapid modernity the Malays had to adapt in midcentury Singapore. In a chapter dedicated to discussing P. Ramlee and his artforms, Hassan Abd. Muthalib (2013) suggested that P. Ramlee "imparted advice and guidance in a very discreet and subtle manner" and portrayed messages using indexes and symbols in visualizing narratives. There are diverse methods in which the director incorporates subtle representations in developing narratives, which include cinematography elements i.e. framing, camera movement, lighting, colour temperature, depth of field, etc. A study of $P$. Ramlee's two renowned heavy dramas, Semerah Padi (1956) and Antara Dua Darjat (1960), found that a lot of cinematography elements were manipulated to represent narrative, which includes the interplay of camera level, similar to that of Japanese auteur Akira Kurosawa's (Hamsan, 2004). Looking into similar film genre; Antara Dua Darjat and Ibu Mertua-Ku, this paper explored P. Ramlee's cinematography style in visualizing cultural values representation.

Constructed by the accounts discussed above, this research aspired to enrich the limited scope of local cinema study, which mainly focuses on film's theme, value and message and explores technical aspects that construct the film contents itself. Cinematography elements are the building blocks of film and had laid the foundation of world cinema, and yet the realm of academia has not seen enough to give them justice (Morgan, 2011). Hence, this study is necessary in order to contribute to the academic investigations on local films specifically on directors' exploitation of technical aspects in film production. 


\section{CONCEPT AND DEFINITION}

\section{Cinematographic Visual Narrative}

The film narrative is foremost created in the form of a written script, and the act of filming the narrative is visually and aurally telling the story. Cinema is an aesthetic medium of image and sound; which makes up a fiction film (Van Kets, 2018). Fiction film is a "window" through which preceded stories audiences had potentially seen somewhere else are exhibited to them (Bordwell, 2007). Thus, through the manipulated poetic language of cinema such as cinematography conceptual tools, visual narratives are then formed.

Van Kets (2018) in her research on cinematographers' influence in film production further defined visual narrative construct as a concept to "understand the visual meaning of a shot and its link with filmic tools. We examine the intersection of perception, the human brain, and filmic technique" (p. 38). Visual narrative facilitates the researcher in identifying the representation of visual framed by cinematography techniques as attention, frame and cinematic space. Therefore, this paper conceptualized visual narrative through an in-depth look into cinematography techniques utilized and their contextualization by P. Ramlee in his film texts.

\section{Cinematography and Film Syntax}

Brown (2012) asserted that cinematography is a process by which idea, word, action, emotion, tone and other forms of nonverbal communication are composed into visual storytelling. He added that there are seven conceptual tools of cinematography which are; (1) frame, (2) light and colour, (3) lenses, (4) movement, (5) texture, (6) establishing, and (7) point of view (POV). Brown's assertion was also implied by Monaco (2010) as he described visual narrative as a composition of conceptual tools that communicate cinematic language of film syntax; created by the director through the process of filmmaking. In such a manner, film syntax is a systematic guide to understand cinematographic tools in generating meanings.

In the context of this study, the researcher selectively opted for Brown and Monaco's theoretical definitions of cinematography which focus on camera space (synchronic) and camera movement (diachronic). The relationship between synchronic and diachronic was earlier observed by film semiotic guru, Christian Metz and suggested that semiotic connotations have placed cinema as art and that camera framing, movement and lighting combined to create denotation meanings. Referring to Metz's notion, Pramaggiore and Wallis (2011) and Branigan (2006) too proposed two cinematography techniques, (1) camera movement (diachronic) and camera space (synchronic) in exploring film's cinematography techniques. Once the theoretical definitions, examples and coding rules for each embedded subunits were established, the coding agenda is then constructed. The following are the cinematography film syntax; Table 1 is the diachronic cinematography elements, while Table 2 is the synchronic cinematography elements. 
Table 1: Diachronic Cinematography Elements

\begin{tabular}{|c|c|}
\hline Type & Description \\
\hline Pan & Left to right horizontal movement with no changes in camera position \\
\hline Tilt & Up and down vertical movement with no changes in camera position \\
\hline \multirow[t]{4}{*}{ Dolly } & Movement whereby the camera is mounted and moves on a track \\
\hline & Dolly in/out - toward or away from the subject \\
\hline & Dolly left/right - left or right in relation to the subject \\
\hline & Boom up/down - up and down vertical hydraulic movement \\
\hline Tracking & Camera moves alongside and parallels to the subject \\
\hline Handheld & Camera is operated without mounting \\
\hline \multicolumn{2}{|r|}{ Table 2: Synchronic Cinematography Elements } \\
\hline Type & Description \\
\hline High angle & Camera is above eye height \\
\hline Eye-level & Camera is parallel to eye height \\
\hline Low angle & Camera is below eye height \\
\hline Dutch angle & Camera horizontal off-level to the left or right \\
\hline Extreme long shot & $\begin{array}{l}\text { Also known as the establishing shot. Frame the opening shot of } \\
\text { the scene's location }\end{array}$ \\
\hline Long shot & Also known as a wide shot. Framing the overall space of a scene \\
\hline Medium long shot & $\begin{array}{l}\text { Location or space is frame tighter, yet the character is not in full } \\
\text { shot }\end{array}$ \\
\hline Full shot & Character in a full shot - head to toe \\
\hline American shot & $\begin{array}{l}\text { Also known as the cowboy shot. Character is framed from head } \\
\text { to middle of the leg }\end{array}$ \\
\hline Medium shot & Character is framed from head to waist \\
\hline Medium close up & Character is framed from head to mid-chest/stomach \\
\hline Close up & Character is framed from head to top part of chest/pocket \\
\hline Choker & Character is framed from head to chin \\
\hline Extreme close up & Character's body part is framed- eyes, mouth, nose, etc. \\
\hline
\end{tabular}

\section{Cultural Values}

Culture and its value system have been defined and discussed repetitively for which American anthropology Gerald Weiss never found a fitting description. Among the prominent conceptualization of culture was that of Kroeber and Kluckhohn (1952) which state, "Culture consists of patterns, explicit and implicit, of and for behaviour acquired and transmitted by symbols, constituting the distinctive achievements of human groups, including their embodiment in artefacts," Though culture as we understood it is a collective belief system adopted by society, culture according to Kroeber and Kluckhohn is also "though only part, of the personality". Therefore, a collective belief system can be learned and practised by an individual as a member of her/his civil society, yet her/his personality may exercises the cultural values as one wishes. As such, a social artefact created by an individual from a collective belief system can then be studied to understand its idiosyncrasy of cultural values.

It is very much acknowledged that the Malay culture values are rooted mainly from the teachings of Islam and the pluralistic nature of the Malays. This study had identified the Malay traditional cultural system of 13 values as conceptualized by Mohd Yuszaidy and Muammar (2015). Table 3 is the breakdown of Malay traditional cultural values. The cinema industry and its film texts are visual aids in the construction of culture and "Ramlee's films were used to convey the construction of a particular ideology" (Mahyuddin \& Lee, 2015). Based on these cultural values, P. Ramlee's Antara Dua Darjat and Ibu Mertua-Ku were coded in order to explore the director's visual narrative style of cultural values representation. 
Table 3: Malay Traditional Cultural Value System

\begin{tabular}{ll}
\hline Societal Value System & Character Value System \\
\hline Harmony & Honesty \\
Collective activities & Responsible \\
Teamwork & Diligent \\
Helpful & Gentle \\
Communal & Manners \\
Willpower & Sincere \\
Equal sharing & \\
\hline
\end{tabular}

\section{UTILIZATION OF AUTEUR THEORY}

The role of theory in qualitative research is to support vital methodological processes in ways it guides to construct research objectives, select case study design, or outlining sample and data collection. Theory can be employed to strategize preliminary data collection and generalize the case study findings. Yin (2012) further elaborates that a qualitative case study that engages "theoretical propositions or theory will be easier to implement than one having no propositions". Distinctively quantitative research, a theory is chosen as measures with the decorum of a grand theory while qualitative case study research design employs theory to distinguishes simple relationships between theory propositions, concepts, and findings. Theory-before-research model as endorsed by Yin (2012) and Lune and Berg (2017) will allow case study data collection and analysis to be guided with established key concepts; a much beneficial trait for researchers everywhere.

Originated from a written piece titled The Birth of a New Avant-garde in 1948, Alexander Astruc induced an idea asserted that a film director is the 'author' of his medium and the camera is his 'pen' (Ben-Shaul, 2007; Pickering, 2010; Stam, 2000). Auteur theory, as the idea later is known, promotes the concept that a director with individual stylistic skills comparatively produces recognizable and distinctive films (Pramaggiore \& Wallis, 2011). According to André Bazin, these individualistic styles are intuitive personal elements that are infused by directors, consciously or unconsciously, into their films (Pickering, 2010; Stam, 2000).

As argument on auteurs (directors) progresses, so did articles on their aesthetic values which filled the pages of France popular film journal, Cahiers du cinema, especially the likes of Hollywood's John Ford, Orson Welles, and Fritz Lang. Nevertheless, it was not until 1962 that auteur theory planted its footing in the American film industry and academia (later globally) when Andrew Sarris wrote Notes on Auteur Theory. Sarris (1962) proposed three criteria of an auteur: (1) technically competence, (2) has a distinguished personality, and (3) the auteur's body of work shares interior meaning defined as an underlying tension between director's vision and the subject matter. Yet, Sarris's third criterion was not defined plainly and further discussed by Pramaggiore and Wallis (2011) as a "continuing elaborating of a director's perspective on the world through the treatment of themes" (p. 409).

Sarris's auteurism redirects the question of 'what' in a story or theme, to 'how' in style and techniques. These styles and techniques alluded to directors' personality, ideology, and idiosyncrasy (Stam, 2000). Techniques and style were emphasized by Sarris as essential in auteur theory and argued that "if a director has no technical competence, no elementary flair for the cinema, he is automatically cast out from the pantheon of directors. "A great director (auteur) has to be at least a good director" (Sarris, 1962, p. 1). Thus, founded by Sarris's notion, studies on auteurs have expanded toward directors' technical finesses on colour, lighting, mise-en-scéne, cinematography, etc. Watson (2012) also suggested that the emergence of 
authorship has allowed artistic and academic legitimacy of cinema as a form of traditional arts, which qualify intellectual inspections and interpretation of film style. Therefore, clearly defining individual films and the director's artistic merits.

\section{CONCEPTUAL FRAMEWORK}

According to Merriam and Tisdell (2016), the terms theoretical framework and conceptual framework are unnecessarily interchangeable in the realm of research, both quantitative and qualitative depending on writers' preferences. Therein, this researcher chooses to utilize the term conceptual framework to discuss the relationships among theory and concepts adopted in this study to understand P. Ramlee's auteurship in the visual narrative representation of cultural values.

A conceptual framework is the scaffolding of research that it works as a fundamental structure which comprises of theoretical propositions and concepts. Referring to Figure 1, this study will look into film, particularly P. Ramlee's Antara Dua Darjat and Ibu Mertua-Ku. Through case study embedded data collection and analysis, the director's style in the visual narrative representation of cultural values will be examined under auteur theory propositions that a great director or auteur are; (1) technically competence, (2) has a distinguished personality, and (3) the auteur's body of work share interior meanings, defined as an underlying tension between director's vision and the subject matter.

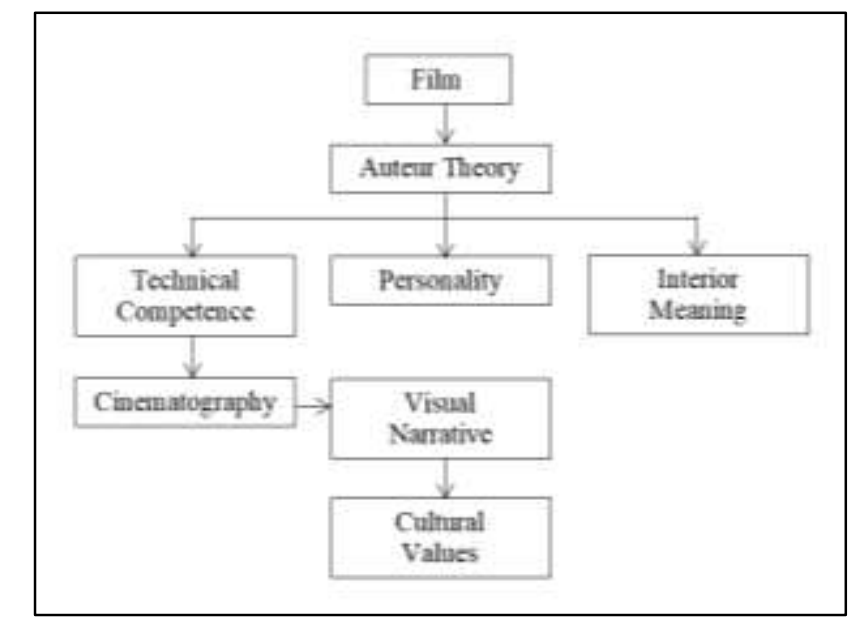

Figure 1: Conceptual Framework of P. Ramlee's Auteurship in Visual Narrative Representation of Cultural Values.

\section{RESEARCH DESIGN}

This study was conducted with an aim to understand P. Ramlee's auteurship in the visual narrative representation of cultural values. The researcher focuses on the Golden Era of Malayan films of the 1950s and 1960s, whereby film texts selected were two heavy drama films by P. Ramlee; (1) Antara Dua Darjat and (2) Ibu Mertua-Ku. Produced in 1960 and 1962 the films' duration are two hours nine minutes and two hours respectively. According to Hamsan Mohamed (2004), heavy drama film carries substantial manipulation of cinematography elements in supporting its narrative, thus befits this study's exploration of Antara Dua Darjat and Ibu Mertua-Ku.

This study employed an interpretive social science paradigm that aims at understanding human interactions with each other and systematically analyzes socially meaningful actions. To understand humans, the paradigm believes in directly observing 
people in their natural settings for the purpose of understanding and interpreting their cultural artefacts (Neuman, 2014). A qualitative case study research design was employed to "search for meaning and understanding, (whereby) the researcher as the primary instrument of data collection and analysis, an inductive investigative strategy, and the end product being richly descriptive" (Merriam \& Tisdell, 2016). A case study research design is an in-depth examination of a contemporary phenomenon, which further identified as a case in a bounded system. An inquiry with a bounded system as suggested by Merriam and Tisdell (2016) supported Yin's notion of case study research design, whereby the case itself serves as the main unit while incorporating embedded subunits; a vision of a systematic data collection and analysis procedures (Lune \& Berg, 2017; Yin, 2012).

The framework of this study explored P. Ramlee's Antara Dua Darjat and Ibu Mertua$\mathrm{Ku}$ as the main unit of analysis, which is bounded by a system of cinematography film syntax. By systematically organizing the case or film text into a well-defined categorical aggregation of cinematography film syntax subunits, the researcher sought to draw meanings from the emerging patterns. To guide the data collection and analysis, the study adopted key concepts of cinematography elements from works of literature and further constructed a coding agenda. As data collection progressed, new emerging key concepts of cinematography elements were incorporated and analyzed on their representation of cultural values. Lune and Berg (2017) explained further that in a descriptive case study research design, the researcher established a framework to be used throughout the study. This design required the researcher to construct the unit of analysis prior to data collection.

Film as a sample consists of multiple embedded units of analysis and in this research, the coding agenda focuses on two main categories; (1) cinematography film syntax and, (2) cultural values. The gathering of these subunits involved defining each subunit from multiple documents and observations. In the end, the researcher constructed a coding agenda by referring to subunit defined by Brown (2012), Monaco (2010) and Mohd Yuszaidy Mohd Yusof and Muammar Ghadaffi Hanafiah (2015). In order to test the validity and reliability of the coding agenda and intercoder, a pilot study was conducted on another P. Ramlee's film.

\section{Pilot Test and Intercoder Reliability Test}

Prior to conducting data collection and analyses on selected film texts, it is utmost compulsory to conduct a pilot study to make certain that the actual data-gathering effort is smooth and manages to produce influential findings. A pilot study is essential in making sure that the coding agenda constructed is sufficient and practical in fulfilling the research objectives posted at the beginning of this study (Wan Hartini, 2018).

A pilot study is a small scale data collection and analyses practice of projected research in order to assess the coding agenda's workability as a research instrument. For this pilot study, three intercoder; one main coder and two intercoder, were assigned with three subplot scenes from P. Ramlee's first film, Semerah Padi. The subplot was segmented into three parts; beginning, middle and end. Though the combination of shots generates meanings, an individual shot is a film's simplest subunit which able to demonstrate cinematography techniques. By reading into each uninterrupted/uncut shot be it motion or static (Speidel, 2012), the researcher managed to understand P. Ramlee's cinematography tendencies.

In pursuance of the coders' reliability, the researcher also adopted Cohen's kappa coefficient to assess the degree of consistency with respect to the coding agenda's ability to answer the research question. This study utilized NVivo 12 as a research tool and operating 
Coding Comparison Query in the software has tested the intercoder (including the main researcher/coder) reliability on their analyses of Semerah Padi.

Table 4 Coding Comparison Query of Three Intercoder

\begin{tabular}{ll}
\hline Nodes & Cohen's kappa coefficient value \\
\hline Diachronic shots & 0.913 \\
Synchronic shots & 0.882 \\
\hline
\end{tabular}

Table 4 shows Cohen's kappa coefficients from three intercoder analyses of Semerah Padi. Mayring $(2000 ; 2014)$ identified 0.7 as the minimum value for reliability test and Table 4 shows that both subunits in the coding agenda had a value of 0.913 and 0.882 respectively. Thus, the coding agenda was tested and is reliable to further employ on Antar Dua Darjat and Ibu Mertua-Ku.

\section{FINDINGS AND DISCUSSIONS}

In this section, the findings presented will uncover P. Ramlee's auteur characteristics in his visual narrative representation of cultural values. The enthralling idea that directors' personalities' are infused into their texts instigated this study of looking into P. Ramlee's technical filmmaking prowess in representing culture. According to Hassan Abd. Muthalib (2013), studies on technical aspects of filmmaking such that of cinematography are limited, which is ironic since the fundamental built of films is the equipment and the employment of the tools in constructing a visual narrative. Based on Andrew Sarris's Auteur Theory, the findings elaborates the following traits of auteur; (i) technical competence, (ii) distinguished personality, and (iii) auteur's body of works share interior meanings.

The exploration into P. Ramlee's utilization of cinematography tools in constructing his visual narrative has brought forward the recurring and distinguishable style of the director. Looking at selected cinematography tools as meaning-making implements, the film syntax of cinematography is divided into two categories; synchronic shots and diachronic shots. Synchronic shots can be understood as the distance and framing angle of a subject on camera, while diachronic shots are two dimensional and three-dimensional movement of the camera.

From the analyses done, P. Ramlee has established a distinctive style on framing his actors and their actions, which in doing so exposed his technical competence in filmmaking. The synchronic shots in both films were mostly framed at eye level angle regardless of the positions; actors could be up on their feet, seated or even laid on their back. Bringing the audience to a similar eye level to the actors or actions is a fundamental convention in filmmaking. This practice is important to institute a relationship between audience and actors on the screen. Diachronic shots were sparingly utilized in both films. This could be due to the fact that film cameras in the 1950s were bulky and heavy, which would make moving them, be it on a dolly or track a feat on its own. In both films, there was no three-dimensional movement visualization of cultural values utilized. On the other hand, two-dimensional camera movements especially pan were utilized distinctly, carrying vital motivations of cultural values portrayed to them.

Through case study embedded analysis and thematic analysis, it is apparent that $P$. Ramlee had mastered technical competence. He utilized the fundamental convention of filmmaking accordingly, such as the employment of high and low angles to manipulate the appearance of power on its subjects and best utilization of limited camera lens variants. Second-hand equipment was brought in from Shaw's Shanghai studio and wide-angle short 
focal length lenses very commonly used in the early Malayan film industry. One of which was the communal scenes in both Antara Dua Darjat and Ibu Mertua-Ku. To be able to frame actions smoothly with multiple actions simultaneously happening at the same time in-frame requires a director to be technically competent and capable of directing big casts.

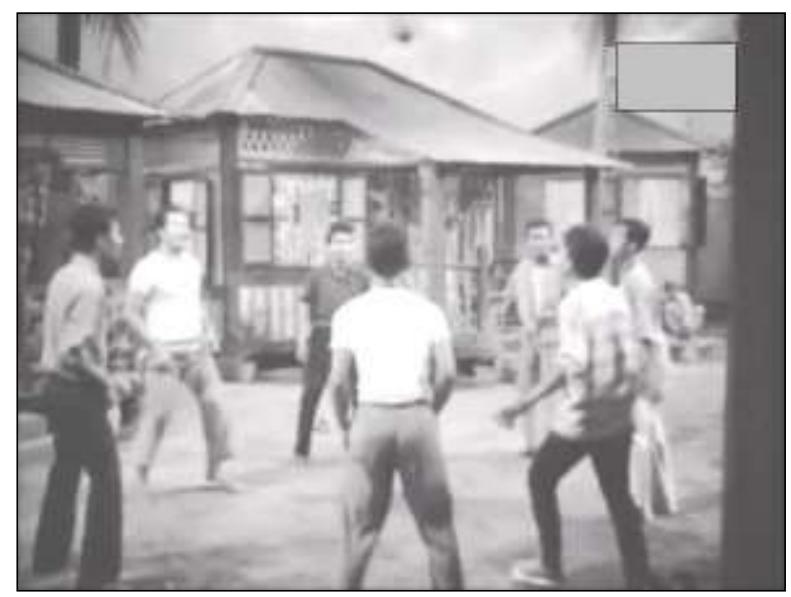

Figure 2: Communal space framed in long shots in Antara Dua Darjat

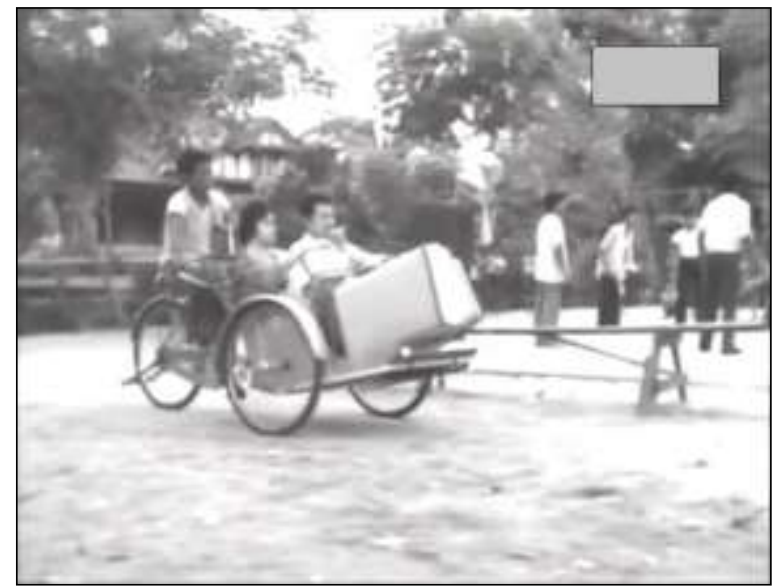

Figure 3: Communal space framed in long shots in Ibu Mertua-Ku

Figures 4 and 5 portray P. Ramlee's idiosyncrasy in utilizing conventional film syntax in emphasizing his storytelling. The final confrontation scene of aristocrat and commoner in Antara Dua Darjat, Ungku Mukri was shot at a high angle not only as a point of view of Ghazali (standing) but also a statement made by the director. The notion was meant to criticize the Malay society's obsessions towards status, inheritance, and title. Referring to Figure 5, in a scene of Ibu Mertua-Ku, after marrying Kassim Selamat and Sabariah off Nyonya Mansoor announces to the gathered party that Sabariah is no longer her daughter. The position of the newlyweds on the floor permitted a point of view shot such as the frame below. However, this low angle shot also portrayed the power and authority of Nyonya Mansoor. This choice of angle on framing Nyonya Mansoor can be seen utilized by P. Ramlee throughout the film. 


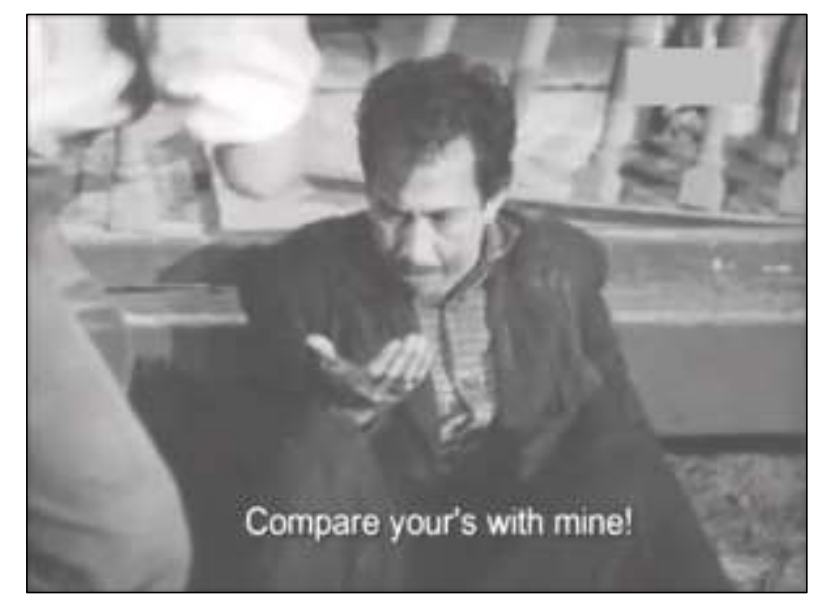

Figure 4: Synchronic high angle of Ungku Mukri

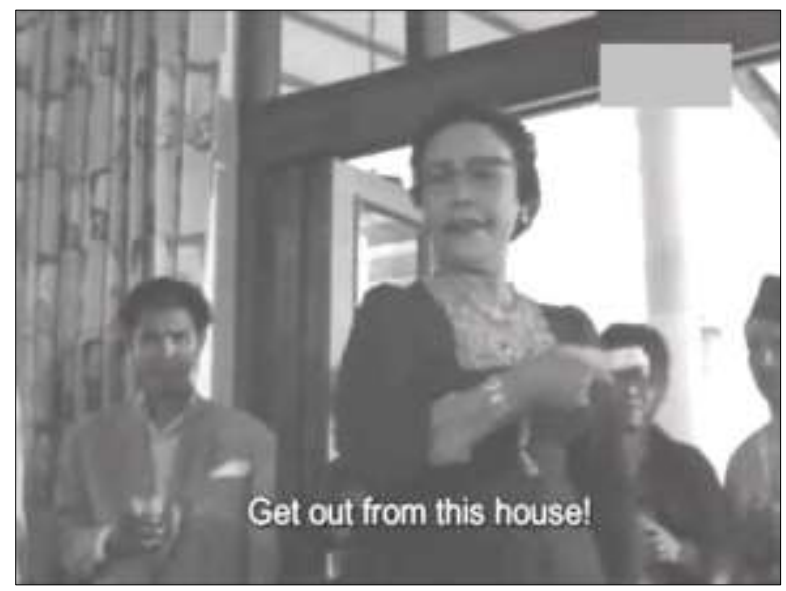

Figure 5: Synchronic low angle of Nyonya Mansoor

The second characteristic of an auteur is distinguished personalities infused by the director into his films. During the 1950s Malayan Golden Era Cinema, directors were in-house staffs of their studios. The two most prominent studios were Malay Film Productions (MFP) where P. Ramlee worked, and Cathay-Keris Films Production (CKFP). There were noteworthy differences in films produced during the time and one being that each studio produced a specific trait of films regardless of directors. At some point in the mid-50s and early 1960s, MFP continued on producing melodramas while CKFP moved into producing films about local folklores such as their infamous Pontianak series, Dang Anom, Tun Fatimah and the renowned Hang Jebat, directed by Hussein Haniff. The studio system dictated types and styles of film, which in many ways restricted directors' artistic flair to be pronounced in their productions.

However, findings show that despite the top-bottom workflow in film production at the time, P. Ramlee managed to infuse his personalities into his film texts. Known for his social criticism messages in films, P. Ramlee made it a point to have characters conveyed criticism, especially towards the Malays. Films marketed as forbidden love stories such as Antara Dua Darjat and Ibu Mertua-Ku did portray other messages i.e. communal spirit and mannerism. The researcher also noted that the main actor (which was the director himself) in both film texts was portrayed as a musician. This direct incarnation of the director's personality was strongly manifested as P. Ramlee himself was first discovered singing with his band at an agriculture fair in Penang, before moving to Singapore and found stardom. 
The last characteristic of an auteur is shared interior meaning across the body of works. The sample film texts were limited to two films, but similar recurrences can be identified throughout both films. The findings on interior meaning across P. Ramlee's films are aplenty, however, this study specifically explores the director's employment of cinematography tools in representing cultural value. Across both film texts, the director emphasized selected cultural values visually and devised a distinctive cinematographic style in doing so. One particular thought-provoking visual narrative was on the cultural value of responsibility. The character Ungku Aziz in Antara Dua Darjat was devised to portray responsibility and with that a responsibility to correct the feudal minds of both aristocrats and common folks. A similar treatment was portrayed by Mami in Ibu Mertua- $K u$, where her character was responsible to challenge the typecast notion of arrogant and ill-mannered well-off elite women such as Nyonya Mansoor. Mami had multiples similarities to Nyonya Mansoor, a rich single mother with a daughter, and yet P. Ramlee tasked them to portray the extreme ends of humanity.

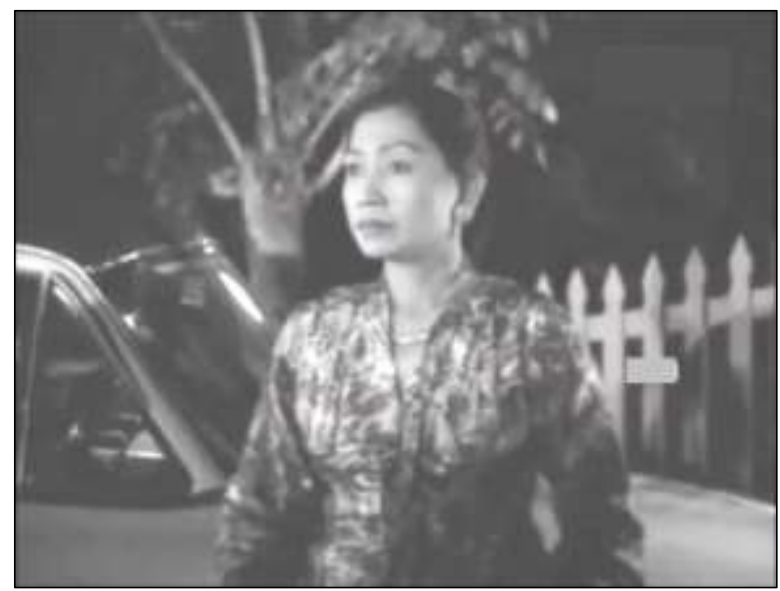

Figure 6: Synchronic medium shot of Mami in Antara Dua Darjat

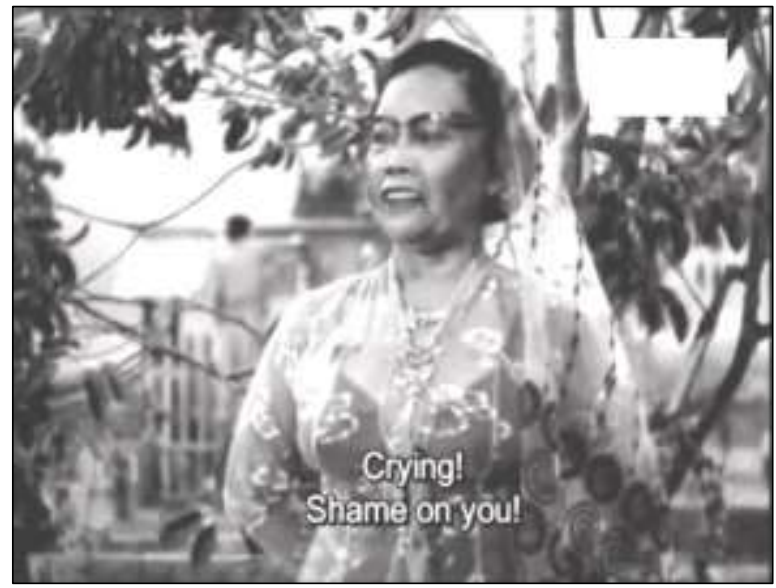

Figure 7: Synchronic medium shot of Nyonya Mansoor in Ibu Mertua-Ku

In another example of character as a carrier to interior meaning, the director stylistically framed Antara Dua Darjat's Ungku Aziz in a synchronic medium shot. A different approach to the way other aristocrat men like Tengku Karim and Tengku Hassan were mostly framed, in American or full shot. This distinguishable difference can be explained through the function of body language and men's physical dominance. The Tengku's were mostly framed looser to show their authoritative and intimidating gestures, while as for Ungku Aziz his most 
dominant trait was his liberal mind, which required tighter shots to emphasize his wisdom rather than that of his tall stature.
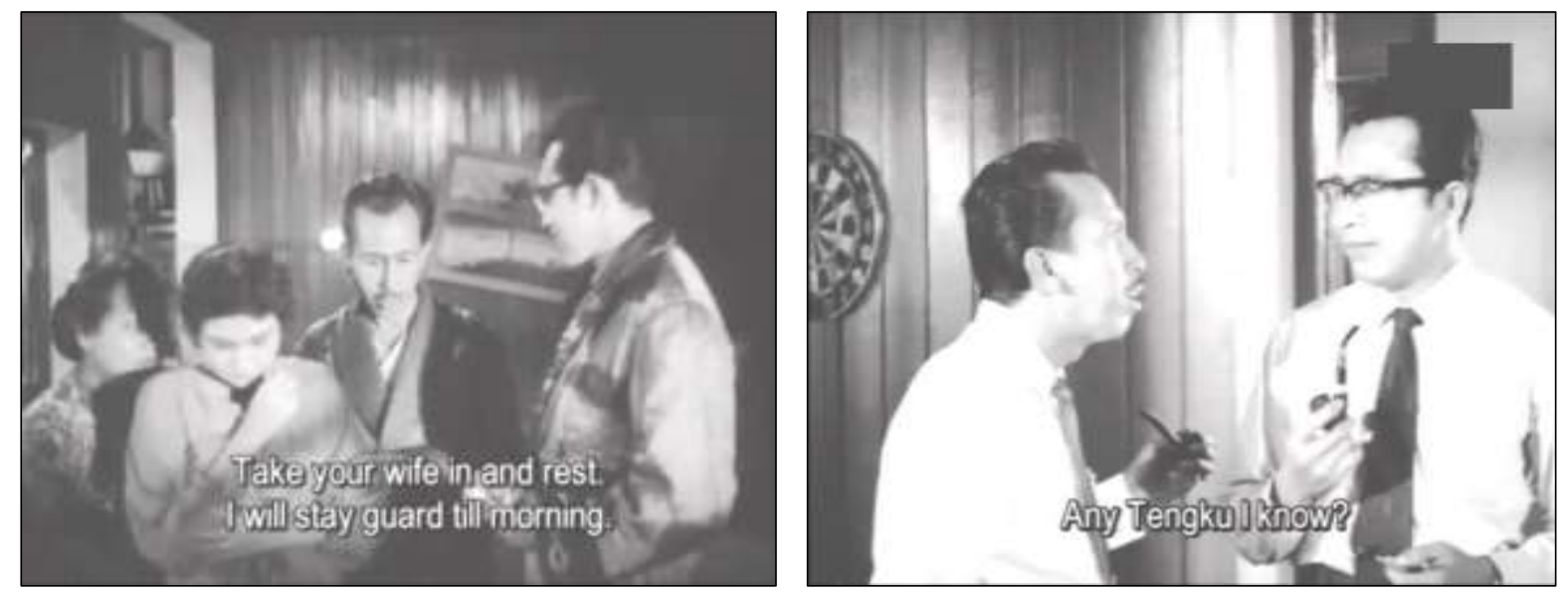

Figure 8: Synchronic medium shots of Ungku Aziz
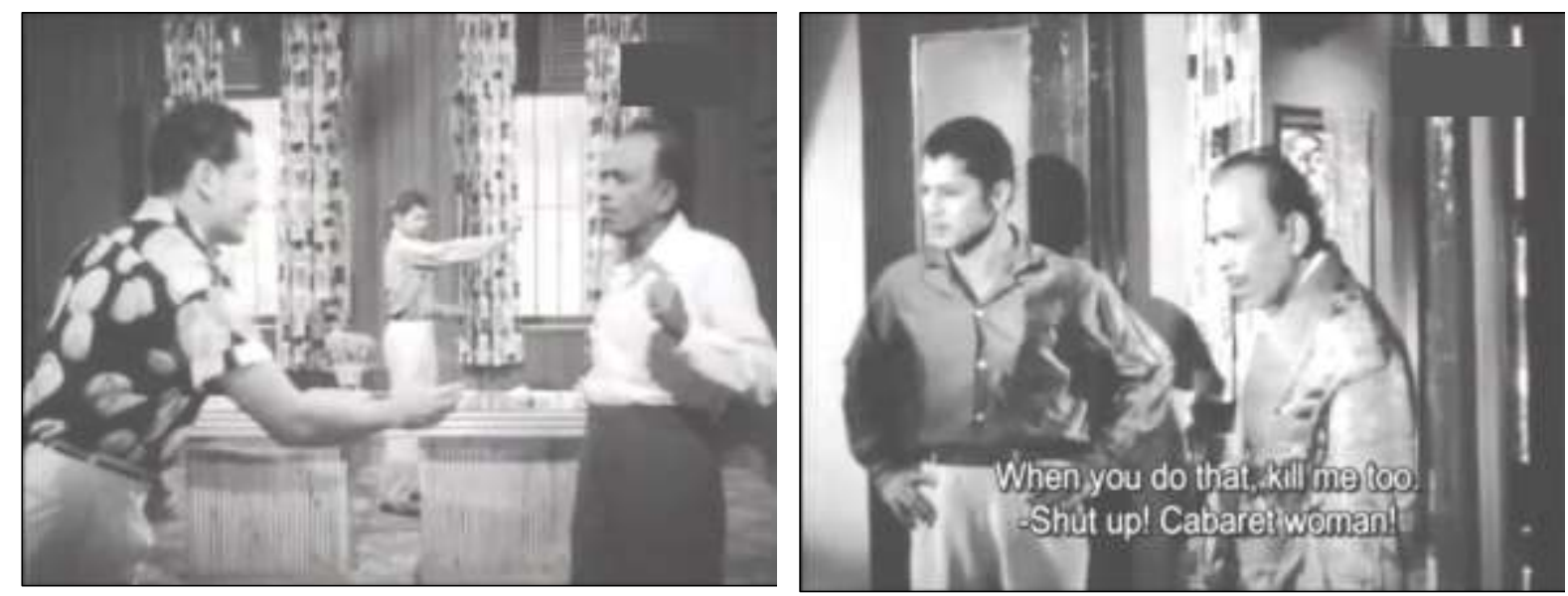

Figure 9: Synchronic American shots of Tengku Karim and Tengku Hassan

In Ibu Mertua-Ku, a character by the name Abang Ali encompassed the traditional Malay character value of manners. Abang Ali is Kassim Selamat and Sabariah's landlord in Penang. Through and through, Abang Ali addressed Kassim Selamat as "Encik Kassim", even after the man had lost sight and was living off of Abang Ali's charity and compassion for almost two years. One particular highlighted gesture of manner detailed by the director in the film through Abang Ali was the way he excused himself from Kassim Selamat and Sabariah's room. In two separate scenes, Abang Ali verbally excused himself and walked passed his tenants with his head lowered and hand pointed to the floor leading his steps, in a gesture of respect and politeness. In both scenes, the director followed Abang Ali's movement with a diachronic pan right shots. 

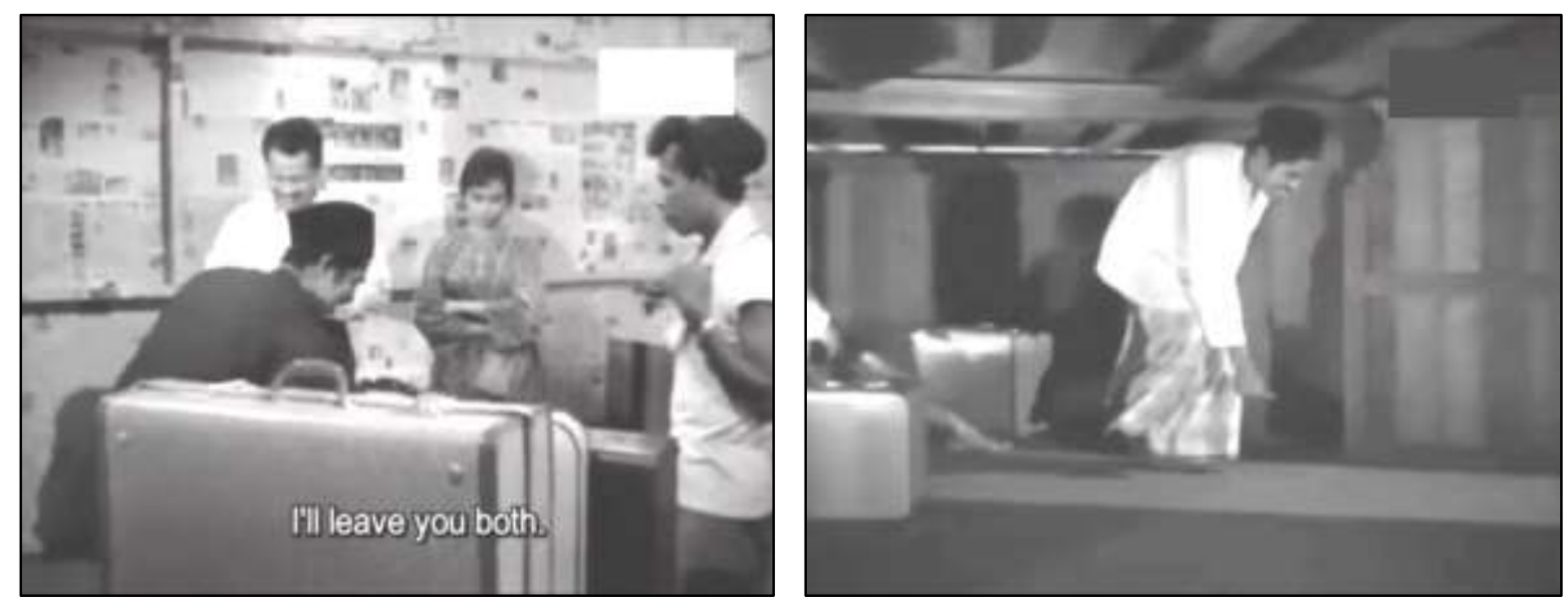

Figure 10: Diachronic pan right shots of Abang Ali in Ibu Mertua-Ku

The notion of brotherhood was momentously represented in Antara Dua Darjat and Ibu Mertua-Ku. Both films offered groups of men in music bands; one a local village band while the other a popular orchestra broadcasted on the radio with fans to boot. The societal value of brotherhood was narrated visually in a similar manner repeatedly in the films. Despite being marketed as love stories, the director took great care in portraying the musical men as a small unit, a significant addition to the society they were part of.

The representations of brotherhood as societal values were comparable in both Antara Dua Darjat and Ibu Mertua-Ku. The men were mostly framed in synchronic medium and at times full shot, a choice of framing the director employed to permit all "brothers" visibly composed in a frame. Figures 11 and 12 are two visual narrative instances of brotherhood representation in intense situations. In Figure 11, the men were gathered to search for Ghazali who was beaten by the Tengku's goons, while in Figure 12, Kassim Selamat was accompanied by his band members when he was summoned by Nyonya Mansoor. The tightly framed medium shots portrayed the strong bond of brotherhood among these men, a recurring style identifiable throughout the films.

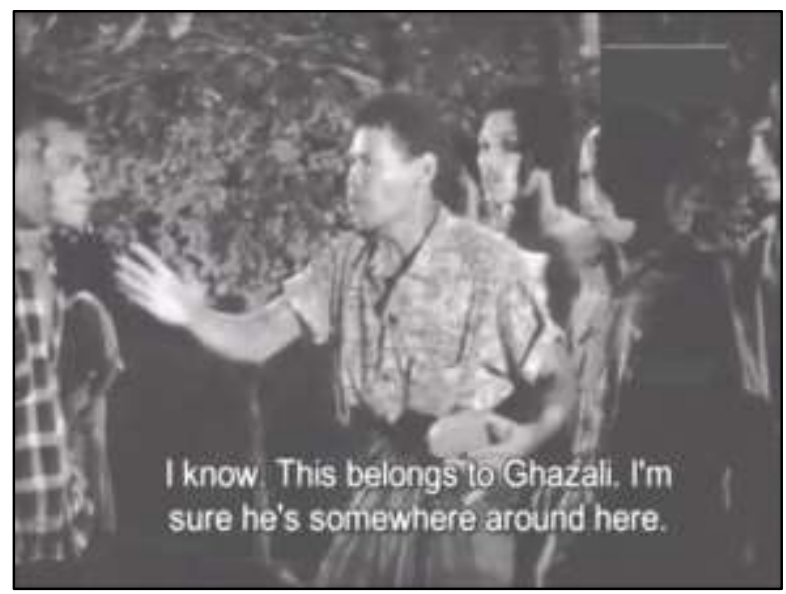

Figure 11: Synchronic medium shot of the brothers in Antara Dua Darjat 


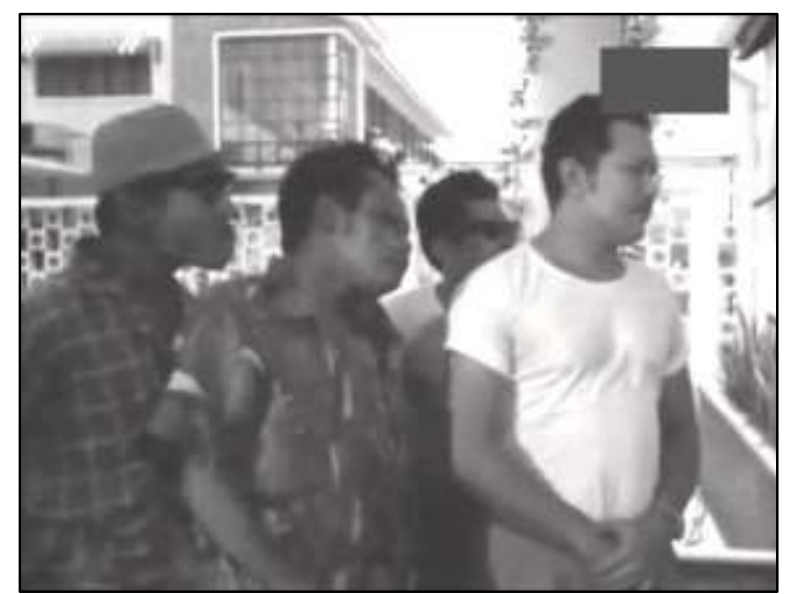

Figure 12: Synchronic medium shot of the brothers in Ibu Mertua-Ku

The study on P. Ramlee's auteurship in devising cultural representation through visual narrative cinematography tools in sum managed to uncover the director's cinematographic style, how he represented cultural values and how he fulfilled auteur characteristic in doing so. The findings saw P. Ramlee's aptitude in employing synchronic and diachronic shots with motivations. Shots were constructed with proper planning as every element in frame served a purpose. Though compared to cinematic film such as Semerah Padi, diachronic shots were employed sparingly in both Antara Dua Darjat and Ibu Mertua-Ku. However, those restrictions did not prohibit $P$. Ramlee from fully utilizing pan and tilt as important framing elements. The distinctively unique choice of synchronic and diachronic shots employed also demonstrates $P$. Ramlee's consistency and prowess in the art of visual narrative. In representing cultural values P. Ramlee was careful to be subtle and to not meddle with the core narrative. The findings suggest that in portraying cultural values of communal, brotherhood, responsibility and manners, P. Ramlee was consistent in devising distinguishable cinematography style. With keen eyes, these cultural values can easily be identified by not only researchers and critics but also by everyday audiences.

Thereupon, it is apparent that P. Ramlee should be placed in the realm of the auteur as he fulfilled all three characteristics of an auteur which are (i) technical competent, (ii) distinguished personality, and (iii) auteur's body of works share interior meanings. P. Ramlee has demonstrated his competence in manipulating cinematography tools and mastering its film syntax. In devising his frame, P. Ramlee invested in every actor and action taken place in frame purposefully. Rather than solely relying on actors' spoken words, P. Ramlee employed visual narrative in amplifying the story indexes. At the end of the day, a forbidden love story by P. Ramlee is never just another love story. P. Ramlee captured his personality and interior meanings attentively throughout his films.

\section{THE INTRODUCTION OF CULTURAL VALUE IN AUTEUR THEORY}

Auteur Theory was first introduced in the 1930s French New Wave Cinema, with a similar notion as discussed in the 1950s Malayan Golden Era Cinema, whereby French critics addressed American directors' individualism compared to their very own European counterparts (Stam, 2000). American directors back in the early 1930s were crafting their arts in the restricted studio system too, the likes of Warner Brothers and MGM, and yet managed to allude their personal styles of filmmaking to the point that it was distinguishable to the eyes of critics, scholar and audiences alike. 
The introduction of cultural values in Auteur Theory was based on the fact that scholars and critics glorified P. Ramlee not so much on his cinematography style but his aptitude in social criticism film texts, which for the most part was P. Ramlee's discourse on Malay cultural values (Anuar, 2003; Mustafar \& Aziz, 2008). This researcher's conviction is that the cultural value of an individual director's belief system is part of the underlying messages through which the director employed in his body of works. Therefore, this study suggests that in understanding auteurship, the individual director's belief system such as cultural values which is shared between the director and his audiences should be discussed in tandem with the auteur characteristics proposed by Sarris.

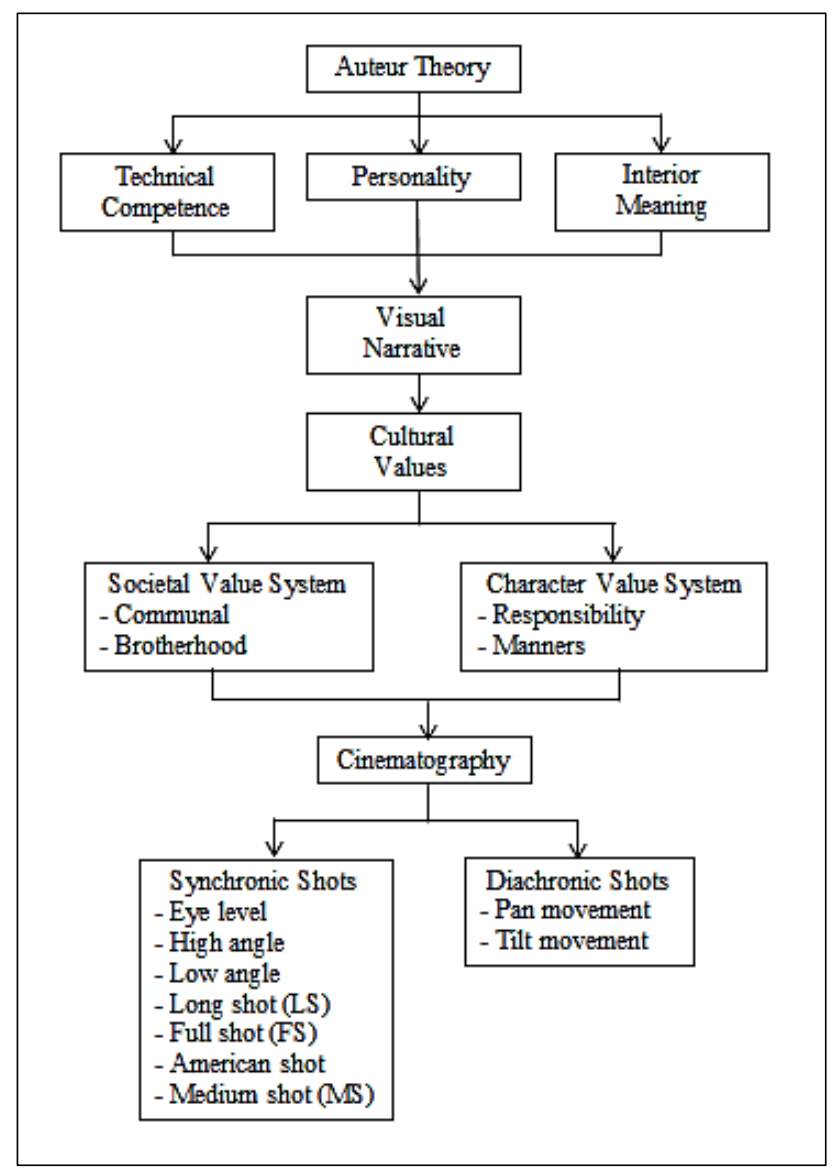

Figure 13: Introduction of Cultural Values in Auteur Theory

\section{CONCLUSION}

Though studies on P. Ramlee are somewhat saturated, this exploration was initially a challenge to the glorified realm in which P. Ramlee was placed by critics and fans. True to the nature of research, this exploration summed up to an outcome which not only agreed to the adoring critics but theoretically characterized P. Ramlee into the realm of an auteur. The exploration of the film is boundless and yet researchers at times are restricted by research trends. The future researchers might, therefore, consider challenging other more contemporary filmmakers such as Mamat Khalid, Shuhaimi Baba, Yasmin Ahmad, Liew Seng Tat, Amir Muhammad, Fahmi Reza or Quek Shio Chuan. It is also suggested that similar research be conducted using qualitative content analysis or audience research using a focus group approach to diversify auteur study on contemporary film texts and audiences. 
BIODATA

Nurul Ezzati Aisya Mohd Zaki is a lecturer at the Faculty of Creative Industries, Universiti Tunku Abdul Rahman, Malaysia. She was a broadcast journalist mainly focusing on TV documentaries. Her teaching portfolio includes video production, media and culture, radio broadcasting, and audio design. Ezzati's research interest includes film studies, representation, semiotics, art intervention, and political economy. Email: ezzatizaki@gmail.com

Wan Hartini Wan Zainodin is a senior lecturer at the Faculty of Communication and Media Studies, Universiti Teknologi MARA, Shah Alam Selangor. She is presently the Head of Postgraduate Studies (FKPM), the chair of the Research Committee of the faculty and also a former coordinator of Research, Industrial Linkages, and Alumni. From 2001 till 2008, she worked at several production houses and TV stations as a broadcast journalist, editor, scriptwriter, and researcher. For the past eight years, she has taught Mass Media Research and Psychology as part of the Liberal Arts Subject in the faculty. Her area of interest is social media, new media, politics, and broadcasting/film-related research. Email: wanhartini@salam.uitm.edu.my 


\section{REFERENCE}

Abdullah Hussain. (2003). Liku-liku hidup P. Ramlee: Tokoh legenda sepanjang zaman. In Rahani Jamil, Abdul Latiff Abu Bakar, \& Ahmad Abd. Kadir (Eds.), P. Ramlee: Seniman agung dunia Melayu: Himpunan kertas kerja simposium karya seni Seniman Agung $P$. Ramlee (pp. 11 -42). Kuala Lumpur: Arkib Negara.

Anuar Nor Arai. (2003). Ramlee: Aspek kemasyarakatan, sinematografi dan pengarahan dalam film 'Semerah Padi', 'Antara Dua Darjat' dan 'Ibu Mertua-ku'. In Rahani Jamil, Abdul Latiff Abu Bakar, \& Ahmad Abd. Kadir (Eds.), P. Ramlee: Seniman agung dunia Melayu: Himpunan kertas kerja simposium karya seni Seniman Agung P. Ramlee (pp. 125-156). Kuala Lumpur: Arkib Negara.

Ben-Shaul, N. S. (2007). Film: The key concepts. New York: Berg Publishers.

Branigan, E. (2006). Projecting a camera language-games in film theory. New York: Routledge. Bordwell, D. (2007). Poetics of cinema. London, UK: Taylor and Francis Ltd.

Bordwell, D., Thompson, K., and Smith, J. (2016). Film art: An introduction (11th ed.). New York: McGraw-Hill.

Brown, B. (2012). Cinematography theory and practice: Image making for cinematographers and directors (2nd ed.). Waltham, MA: Focal Press.

Hamsan Mohamed. (2004). Kepengarahan dan sinematografi P. Ramlee dan Hussein Haniff. Kuala Lumpur: Penerbitan Universiti Malaya.

Hassan Abd. Muthalib. (2013). Malaysian cinema in a bottle a century (and a bit more) of wayang. Petaling Jaya, Malaysia: Orange Dove.

Kroeber, A. L., \& Kluckhohn, C. (1952). Culture: A critical review of con-cepts and definitions. Peabody Museum of American Archaelogy and Ethnology, 47(1).

Lune, H., \& Berg, B. L. (2017). Qualitative research methods for the social sciences (9th ed.) Essex, England: Pearson Education Limited.

Mahyuddin Ahmad, \& Yuen Beng Lee. (2015). Negotiating class, ethnicity and modernity: The 'Malaynisation' of P. Ramlee and his films. Asian Journal of Communication, 25(4), 408-421. https://doi.org/10.1080/01292986.2014.968595

Mayring, P. (2000). Qualitative content analysis. Forum: Qualitative Social Research, 1(2). http://dx.doi.org/10.17169/fqs-1.2.1089

Mayring, P. (2014). Qualitative content analysis: Theoretical foundation, basic procedures and software solution. Forum: Qualitative Social Research. Retrieved from http://nbnresolving.de/urn:nbn:de:0168-ssoar-395173

Merriam, S. B., \& Tisdell, E. J. (2016). Qualitative research: A guide to design and implementation (4th ed.). San Francisco, CA: Jossey-Bass.

Metz, C. (1974). Film language: A semiotics of the cinema. New York: Oxford University Press.

Mohd Yuszaidy Mohd Yusoff, \& Muammar Ghaddaffi Hanafiah. (2015). Impak media baharu terhadap sistem nilai masyarakat Melayu di Malaysia. Jurnal Komunikasi: Malaysian Journal of Communication, 31(2), 33-46.

Monaco, J. (2010). How to read a film: Movie, media and beyond. New York: Oxford University Press.

Morgan, D. (2011). Maz Ophuls and the limits of virtuosity: On the aesthetics and ethics of camera movement. Critical Inquiry, 38, 127-163.

Muhammad Hatta Muhammad Tabut. (2003). Kandungan dan teknik: Unsur-unsur yang mempengaruhi filem tempatan. In Ramli Mohamed (Ed.), Sinema dan penontonan di Malaysia (pp. 26 -44). Penang: Penerbitan Universiti Sains Malaysia. 
Mustafar Abdul Rahim, \& Aziz Satar. (2008). Filem-filem P. Ramlee. Senawang, Malaysia: MZA Terbit Enterprise.

Neuman, W. L. (2014). Social research methods: Qualitative and quantitative approaches (7th ed.). London: Pearson.

Pickering, S. (2010). The Chicago School of media theory: Auteur. Retrieved from http://www.lucian.uchicago.edu

Pramaggiore, M., \& Wallis, T. (2011). Film: A critical introduction (3rd ed.). Boston: Pearson.

Sarris, A. (1962). Notes on the auteur theory in 1962. Film Culture, 27, $1-8$.

Speidel, S. (2012). Film form and narrative. In J. Nelmes (Ed.), Introduction to film studies (pp.79-112). New York, NY: Routledge.

Stam, R. (2000). Film theory: An introduction. Oxford, UK: Blackwell.

Watson, P. (2012). Cinematic authorship and the film auteur. In J. Nelmes (Ed.), Introduction to film studies (pp. 142 - 164). London: Routledge.

Wong, A. W., Pillai, S., \& Ong, P. L. (2018). The golden era of the Malaysian film industry: Crosscultural dialogue and negotiation of ethnicity in a budding nation. Kajian Malaysia, 36(1), 1-24. https://doi.org/10.21315/km2018.36.1.1

Van Kets, M. (2018). The emotions of a lens, A study on cinematography and case studies on the cinematographer's role in the cinematographic discourse of a narrative film (Doctoral dissertation, Ghent University, Belgium). Retrieved from https://biblio.ugent.be/publication/8550640

Yin, R. K. (2012). Application of case study research (3rd ed.). Thousand Oaks, CA: SAGE Publications.

Wan Hartini Wan Zainodin. (2018). Understanding the engagement and consequences of user generated online video and its virality towards generation $\mathrm{Y}$ political inclination (Doctoral dissertation, Universiti Teknologi MARA, Malaysia). Retrieved from http://ir.uitm.edu.my/id/eprint/22262/ 